University of Nebraska - Lincoln

DigitalCommons@University of Nebraska - Lincoln

Faculty Papers and Publications in Animal

Science

Animal Science Department

1999

\title{
Review of New Information on the Use of Wet and Dry Milling Feed By-Products in Feedlot Diets
}

Rick Stock

University of Nebraska-Lincoln, rstock3@Unl.edu

J. M. Lewis

University of Nebraska-Lincoln

Terry J. Klopfenstein

University of Nebraska-Lincoln, tklopfenstein1@unl.edu

C. T. Milton

University of Nebraska-Lincoln

Follow this and additional works at: https://digitalcommons.unl.edu/animalscifacpub

Part of the Animal Sciences Commons

Stock, Rick; Lewis, J. M.; Klopfenstein, Terry J.; and Milton, C. T., "Review of New Information on the Use of Wet and Dry Milling Feed By-Products in Feedlot Diets" (1999). Faculty Papers and Publications in Animal Science. 555.

https://digitalcommons.unl.edu/animalscifacpub/555

This Article is brought to you for free and open access by the Animal Science Department at DigitalCommons@University of Nebraska - Lincoln. It has been accepted for inclusion in Faculty Papers and Publications in Animal Science by an authorized administrator of DigitalCommons@University of Nebraska - Lincoln. 


\title{
Review of new information on the use of wet and dry milling feed by-products in feedlot diets
}

\author{
R. A. Stock*,1, J. M. Lewis $\dagger$, T. J. Klopfenstein $\dagger$, and C. T. Milton $\dagger$ \\ *Cargill Corn Milling, Blair, NE and †University of Nebraska, Lincoln 68583
}

\begin{abstract}
The processing of grains to produce human foods, beverages, or fuel ethanol has resulted in a wide variety of associated feed by-products. Hominy feed and distillers by-products are feed by-products associated with two distinctly different drymilling industries. Hominy feed contains approximately 57\% starch, $11 \% \mathrm{CP}$, and $5 \%$ fat (DM basis). When fed to finishing cattle, hominy feed has approximately $87 \%$ the net energy value of corn. Distillers by-products contain 25 to $32 \%$ CP and 13 to $16 \%$ fat (DM basis). Wet distillers by-products have approximately 97 to 147\% the net energy value of corn. The energy value of wet distillers by-products may be affected by the type of grain used in the fermentation process (corn vs grain sorghum) and the amount of solubles added to the distillers grains. Drying distillers by-products reduces their net energy value but does not seem to affect their protein value. Corn gluten feed (CGF) and corn gluten meal (CGM) are feed by-products of the wet milling industry. Corn gluten feed is composed primarily of bran and steep. Corn gluten feed is lower in both CP (14 to 24\%, DM basis) and escape protein (20 to 30\%, \% of CP) than CGM, but it is high in net energy for gain (90 to 114\% of corn; DM basis). As the proportion of steep increases and bran decreases in CGF, the CP and net energy for gain content increases. When fed to finishing cattle, dried CGF has a lower net energy value than wet CGF. Wet distillers by-products and wet CGF seem to reduce the incidence of subacute acidosis. Because feed by-products have a high nutritional content and are often economically priced, they are excellent sources of energy and protein for feedlot cattle.
\end{abstract}

Key Words: Distillers Grains, Maize Gluten, By-products, Grain, Cattle

\section{Introduction}

The dry and wet milling of grains to produce human foods, beverages, or fuel ethanol is continuing to increase, leading to an increased production of associated feed byproducts. Within the last $10 \mathrm{yr}$, the feeding of distillers byproducts (dry milling) and corn gluten feed (CGF; wet milling) in a wet or semimoist form has received wide acceptance in feedlots. Cattle feeders and nutritionists often confuse the nutrient profiles of hominy feed, distillers by-products, and CGF. The nutrient profiles of these feed by-products may vary widely from plant to plant because each plant may use different grain types in the fermentation process (dry milling) or produce different types of human foods or beverages (wet milling). In addition, the nutritive value of the feed byproducts may be different when fed wet than when fed dried. Thus, it is important to understand the differences between and within the dry- and wet-milling industries in order to understand fully the nutritional value of these feed byproducts.

\section{Discussion}

Dry Milling: Hominy Feed. The dry-milling industry that produces grits, meals, and flours for human consumption is quite different from the dry-milling industry that produces fuel ethanol. As described by Watson (1988), the corn drymilling process, which produces grits, meals, and flours, involves the tempering and degerminating of the corn grain. The objective of this process is to isolate the maximum amount of endosperm while removing as much of the germ and pericarp as possible. Corn is screened initially to remove foreign material, crop residue, fines, and broken kernels, then it is washed and tempered with water or steam to achieve a moisture content of 20 to $22 \%$. Use of a Beall degerminator, as summarized by Alexander (1987), is the principal means by which germ and pericarp are separated from endosperm. This system uses an abrading action to strip away the germ and pericarp while leaving the endosperm intact. However, total separation of corn fractions is incomplete, resulting in residual germ and pericarp remaining attached to the endosperm. These contaminants are subsequently removed via aspiration, screening, and other milling practices. The isolated endosperm continues through the milling process and is sorted by size to yield large, medium, or fine grits, meals, or flours. The combined bran and germ are aspirated to remove the bran, allowing the germ to be expelled or hexaneextracted to remove the oil. Feed by-products of this drymilling process include bran, broken kernels, germ residue after oil extraction, and inseparable fractions of germ, pericarp, and endosperm. These materials usually are combined, dried, ground, and marketed as hominy feed.

Larson et al. (1993b) conducted three trials to determine the nutritive value of hominy feed. The hominy feed contained 56.9\% starch, $25.2 \% \mathrm{NDF}, 11.1 \% \mathrm{CP}$, and $5.3 \%$ fat, and replaced dry-rolled corn. As the level of hominy feed increased $(0,15,30,45$, or $100 \%$ replacement of corn) in a lamb digestion trial, DM digestibility decreased $(\mathrm{P}<.01)$; however, starch digestibility increased $(\mathrm{P}=.09)$. In a finishing trial, yearling heifers were fed hominy feed with or without added fat at $0,13.3$ (.67\% added fat), 26.7 (1.33\% added fat), or $40.0 \%$ ( $2 \%$ added fat) of the dietary DM. Fat addition 
did not interact with hominy feed level. Heifers fed 13.3 or $26.7 \%$ hominy feed consumed more DM (quadratic, $\mathrm{P}=.01$ ) than heifers fed the 0 or $40.0 \%$ diets; however, gain and efficiency were similar (Table 1). In a second finishing trial, steers were fed 0 or $40 \%$ hominy feed with 0 or $7.5 \%$ forage (DM basis). No interactions were detected between hominy feed and forage level. Steers fed hominy feed consumed more $(\mathrm{P}=.05) \mathrm{DM}$, gained similarly, but tended to be less efficient $(\mathrm{P}=.18)$ than those fed dry-rolled corn (Table 2$)$. Results of the two cattle finishing trials indicated that expeller-extracted hominy feed contained $87 \%$ of the net energy of corn when included up to $40 \%$ of the dietary DM.

Dry Milling: Distillers. Alcohol production from grain involves the fermentative conversion of starch to alcohol. One of the advantages of the dry-milling industry is its flexibility in the type and quality of grain that can be used in the fermentation process. Corn, grain sorghum, wheat, barley, or a mixture of two or more grains may be used. In addition, a portion of the grain mix may be of lower quality (Sample grade). In this process, grain is ground and the starch is fermented by yeast to produce alcohol. The fermented mash is then processed by various techniques to remove the alcohol and the large volume of water associated with the residual DM.

The coarse feed particles in the mash may or may not be separated from the liquid before processing through the distillation column. Processing the entire mash through the distillation column generally results in a higher yield of alcohol per bushel fermented. After distillation, the remaining feed slurry contains 5 to $10 \% \mathrm{DM}$ and is called whole or spent stillage. The whole stillage then is either screened and pressed or is centrifuged to remove the coarser grain particles. Another approach is to remove the coarser grain particles before processing through the distillation column. With this method, only the liquid fraction is distilled.

The coarser grain particles removed from the whole stillage may be sold as wet distillers grains (WDG), or they may be dried and sold as dried distillers grains (DDG). The liquid fraction (5 to $10 \% \mathrm{DM}$ ) remaining after separation of the grains is called thin stillage. Thin stillage contains fine grain particles and yeast cells and may constitute up to $40 \%$ of the total residual DM. Thin stillage is evaporated to produce a syrup-like by-product containing 20 to $35 \%$ DM and is called condensed distillers solubles (CDS). The CDS may be dried with DDG to produce dried distillers grains plus solubles (DDGS), may be added to WDG to produce wet distillers grains plus solubles (WDGS), or may be sold as a feed ingredient.

Two-thirds of the original grain DM (corn and grain sorghum only) consists of starch. After fermentation, approximately one-third of the original grain DM is recovered in the whole stillage. Because only the starch is removed during the fermentative process, the other nutrients associated with the grain become more concentrated. For example, $\mathrm{CP}$ increases from approximately $9 \%$ in the original corn grain to $27 \%$ in the whole stillage (DM basis). Oil is not removed in most dry milling processes; thus, distillers by-products are higher in fat. Distillers grains contain high levels of escape protein because the gluten fraction is not removed during processing. Published values may not accurately reflect the nutrient composition of distillers by-products because of differences in type, hybrid, and quality of the grains used, differences in the efficiency of starch conversion, and differences in processing techniques among dry milling plants.

Aines et al. (1987) summarized studies that reported the energy value of distillers grains for beef cattle; the energy value of distillers grains averaged $109 \%$ of the energy value of corn (Table 3). One of the studies summarized by Aines (1987) was a study conducted by Farlin (1981). In his study, WDG containing 25\% DM and 27 to $29 \% \mathrm{CP}$ (DM basis) were fed at $21.25,42.5$, and $63.75 \%$ of the dietary DM replacing dry-rolled corn. Compared with the control diet, the low level of WDG did not alter feed intake, gain, or feed efficiency. However, the intermediate level of WDG increased gain $9.9 \%$ and improved feed efficiency $10.6 \%$. The highest level of WDG reduced feed intake $11.2 \%$, but gain was not affected and feed efficiency was improved $10 \%$.

Larson et al. (1993a) conducted two yearling and calf finishing trials, replicated over $2 \mathrm{yr}$, to determine the energy value of corn wet distillers by-products (WDB; wet distillers grains and thin stillage; Table 4). Treatments consisted of a dry-rolled corn control and three levels (5.2, 12.6, and $40.0 \%$, DM basis) of WDB. Supplemental protein for the control diet was a 50:50 combination (CP basis) of soybean meal and urea. The low level of WDB replaced the same amount of $\mathrm{CP}$ as supplied by soybean meal in the control diet. The medium level of WDB replaced the same amount of $\mathrm{CP}$ as supplied by soybean meal and urea in the control diet. The high level of WDB was designed to use WDB as a source of both protein and energy. Yearlings (Table 5) were 5,10 , and $20 \%$ more efficient (linear, $P<.01$; quadratic, $P=$ .05 ), whereas calves (Table 6) were 2, 6, and 14\% more efficient (linear, $P<.01$ ) when fed 5.2, 12.6, and $40.0 \%$ WDB, respectively. Wet distillers by-products fed at the $40.0 \%$ level contributed $47 \%$ and $29 \%$ more net energy for gain than corn when fed to yearlings and calves, respectively. The higher energy values could not be explained by increased digestibility, but they may be due to a combination of factors (e.g., reduced acidosis, improved energy utilization, and yeast end-products) that would increase the net energy content of WDB.

Ham et al. (1994) compared WDB with one of three composites (based on amount of ADIN) of DDGS. The WDB and DDGS were fed at $40 \%$ of the dietary DM, replacing dry-rolled corn. Cattle fed WDB or one of the three DDGS composites gained faster $(P<.05)$ and were 19 and $10 \%$ more efficient $(P<.05)$, respectively, than cattle fed dry-rolled corn (Table 7). Although gains were similar, cattle fed WDB consumed less feed $(P<.05)$ and were more efficient $(P<.10)$ than cattle fed DDGS. Amount of ADIN in DDGS did not affect efficiency of gain. Wet distillers byproducts and the DDGS composites contained 39 and 21\%, respectively, more net energy for gain than dry-rolled corn. When fed to growing calves (Ham et al., 1994), WDB and the DDGS composites promoted similar daily gains and protein efficiencies. Thus, drying of distillers by-products 
decreases their energy value but does not affect their protein value, provided they are not excessively heated or damaged.

Because WDB may contain some ethanol, Ham et al. (1994) evaluated the effect of adding 5 or $10 \%$ ethanol to lamb finishing diets. The addition of ethanol to the finishing diet did not affect gain, feed intake, or feed efficiency.

In two steer metabolism studies (Ham et al., 1994), diets containing WDG, DDGS, and dry-rolled corn had similar effects on ruminal $\mathrm{pH}$ and total VFA concentrations. Feeding thin stillage or CDS reduced $(P<.10)$ ruminal $\mathrm{pH}$ and tended to reduce acetate:propionate ratio.

Fron et al. (1996) conducted in vitro fermentation experiments to determine whether distillers solubles affected rumen microbiology. In vitro lactic acid disappearance was not stimulated by direct addition of distillers solubles to mixed ruminal contents collected from a steer adapted to a high-concentrate diet. However, if steers were fed distillers solubles for several weeks, culturable counts of starchdegrading and lactic-acid-utilizing bacteria increased, and this coincided with a twofold increase in the in vitro rate of lactic acid fermentation. These data suggest that distillers solubles 1) could be used to selectively manipulate the ruminal microbial population; 2) improve the capacity of the ruminal microorganisms to metabolize lactic acid; and 3) possess nutrients in addition to protein, fiber, and fat that may affect animal performance.

Two conflicting studies have been reported evaluating the energy value of wet sorghum distillers grains. Lodge et al. (1997a) fed finishing diets containing 40\% (DM basis) sorghum WDG, sorghum WDGS, or sorghum DDGS, replacing dry-rolled corn. The distillers grains were produced at a commercial ethanol plant using a blend of approximately $80 \%$ grain sorghum and 20\% corn. Cattle fed diets containing dry-rolled corn, sorghum WDG, or sorghum WDGS were similar in efficiency of gain, but cattle fed sorghum DDGS were less efficient $(P<.10)$ than those fed all other treatments (Table 8). Sorghum WDG, WDGS, and DDGS contained 96,102 , and $80 \%$ as much net energy for gain as corn, respectively. These relative energy values are much lower than the energy values for corn distillers by-products reported by Larson et al. (1993a) and Ham et al. (1994). Fanning et al. (1999) fed diets containing 0 or 30\% (DM basis) WDG from corn or grain sorghum. Addition of either type of distillers grains to diets at the expense of dry rolled-corn increased $(P<.01)$ daily gain and improved feed efficiency $(P<.01$; Table 9$)$. The distillers grains averaged $34 \%$ more net energy for gain than corn, and this agrees with the results of Larson et al. (1993a) and Ham et al. (1994). It is not clear why the results of these two studies differed. Potential variables included 1) differences in grain hybrids fermented;2) greater variation in grain sorghum distillers grains; 3) drymilling procedures were different between the studies; and 4) animal variation among studies.

Wet Milling. The process of wet milling is more complex than either of the processes involved in the dry-milling industries previously discussed. The number and types of food products that can be made in the wet-milling industry are numerous. The primary goal of the wet-milling process is to separate the starch from the kernel. Because most of the products that are produced are destined for human food consumption, quality of the grain source is critical. In the United States, only \#1 or \#2 grade corn is used in the wet-milling process. Blanchard (1992) detailed the process of wet milling. Briefly, corn is screened to remove crop residue, fines, and broken kernels and is steeped in a dilute sulfurous dioxide solution for 40 to $48 \mathrm{~h}$. Through a series of grinds, differential separations, and centrifuges, the kernel fractions are separated. The primary component to be isolated is starch. Starch may be dried and sold as-is or converted to a wide variety of products, including corn syrups and highfructose corn sweetener. Some milling plants convert starch to dextrose, which is then used as an energy source for various microbial fermentations. Dextrose may also be fermented by yeast to fuel ethanol. A feed by-product of the alcohol production is distillers solubles. Distillers solubles produced by the wet-milling industry contain yeast cells and unfermented sugars, but unlike CDS they do not contain high levels of fat.

Another fraction that is separated in the wet-milling process is corn germ. Corn germ is separated, dried, and sent to a germ plant for extraction of the corn oil. After the oil is extracted, the remaining feed by-product is called corn germ meal. Corn gluten meal is also separated during the wetmilling process. Corn gluten meal is high in CP and escape protein and is primarily used by the pet food and poultry industries. Today, very limited quantities of corn gluten meal are found in CGF.

The remaining fractions are bran and steep liquor (liquid separated after steeping). Bran and steep liquor are the major components of CGF. During the separation process, bran is pressed to remove much of the water. Pressed wet bran usually contains approximately $40 \%$ DM. Steep liquor and distillers solubles are either evaporated separately or together to approximately 40 to $50 \% \mathrm{DM}$. The majority (70 to $75 \%$ ) of the CGF produced in the United States is shipped to Europe and marketed as dried CGF pellets. Within the last $10 \mathrm{yr}$, an increased amount of wet CGF has been sold directly to feedlots. In most cases, the wet bran cannot absorb all the steep that is produced by the plant, requiring some of the steep to be dried and sold with CGF pellets or requiring a portion of the plant's steep production to be sold as a separate feed ingredient. Consequently, wet CGF may vary in CP content (14 to $24 \%$, DM basis) from plant to plant because varying amounts of steep are being added to the wet bran. Thus, the type of wet CGF produced differs among wet-milling plants. Some wet-milling plants pre-dry the wet bran to $85 \% \mathrm{DM}$ before adding the steep, thereby increasing the proportion of steep in the wet CGF. Therefore, CGF does not have a consistent nutrient profile among wet-milling plants. In summary, CGF may be sold wet (40 to 60\% DM) or dry, and it may contain various quantities of bran, steep liquor, distillers solubles, germ meal, and cracked corn screenings, as well as minor quantities of end-products from other microbial fermentations.

Several summaries have been reported evaluating the research with wet CGF conducted before 1990 (Green et al., 
1987; NCR 88, 1989). In general, the net energy value of wet CGF was reported to be 93 to $100 \%$ of corn. In most early studies, the proportion of ingredients constituting the CGF was not discussed and likely was not known by the researchers.

Researchers at the University of Nebraska have conducted several studies over the past 8 yr evaluating CGF and its components. Two different wet CGF have been evaluated. The first wet CGF (WCGF-A) was composed of wet bran and steep (mixture of steep liquor and distillers solubles) and contained 40 to $42 \% \mathrm{DM}$ and 15 to $18 \% \mathrm{CP}$ (DM basis). Seven studies were conducted in which WCGF-A replaced various levels of dry-rolled corn or high-moisture corn. When averaged across all CGF levels, WCGF-A was similar to corn grain in efficiency and net energy for gain. When averaged across CGF levels typically fed in feedlots (20 to 60\%, DM basis; Table 10), WCGF-A decreased DM intake $.03 \%$, increased ADG .4\%, and decreased feed:gain .3\%. The net energy value of WCGF-A was estimated to be $1 \%$ more than that of corn.

The second wet CGF (WCGF-B) was composed of dry bran, steep (steep liquor and distillers solubles), and germ meal and contained $60 \% \mathrm{DM}$ and 20 to $25 \% \mathrm{CP}$ (DM basis). Five studies were conducted in which WCGF-B replaced various levels of dry-rolled corn. When averaged across all CGF levels, WCGF-B decreased feed:gain $4.9 \%$ and was estimated to contain $13 \%$ more net energy than corn. When averaged across CGF levels typically fed in feedlots (20 to $60 \%$, DM basis; Table 11), WCGF-B increased DM intake $5.4 \%$, increased ADG $11.4 \%$, and decreased feed:gain 5.1\%. The net energy value of WCGF-B was estimated to be $15 \%$ more than that of corn.

The major nutrient differences between these two wet CGF are that WCGF-B is higher in DM (60 vs 40\%) and CP (22 vs $17 \%$, DM basis) and lower in NDF (37 vs $48 \%$, DM basis). The $\mathrm{CP}$ content is higher and the NDF content is lower because of a greater proportion of steep and less bran in the product. Steep liquor contains more energy than bran (Scott et al. 1997b; Herold et al., 1999), and increasing the proportion of steep improves feed efficiency (Figure 1). In addition, germ meal contains more energy than bran (Herold et al., 1998; Herold et al., 1999), and replacing a portion of the bran with germ meal will improve feed efficiency (Figure $1)$.

Although bran contains less energy than steep, it is an important component in reducing subacute ruminal acidosis. Scott et al. (1997b) fed 15 or $30 \%$ dry bran (DM basis) to individually fed finishing cattle. The $15 \%$ dry bran treatment increased $(P<.01)$ DM intake, daily gain, and efficiency (Table 12) compared with the control diet, likely due to reduced acidosis. The 30\% dry bran treatment reduced $(P<$ .01 ) efficiency compared with the $15 \%$ bran treatment, suggesting that bran has less energy than the dry-rolled corn it replaced and that the $15 \%$ bran was sufficient to reduce acidosis. Feed efficiency for the $30 \%$ bran treatment was still equal to that of the control diet, likely because of the combination of acidosis control and energy content.
Krehbiel et al. (1995) evaluated the effects of feeding WCGF-A on subacute acidosis. In a metabolism trial, ruminally fistulated steers were dosed with $100 \%$ corn, $50 \%$ corn: $50 \%$ WCGF-A, or $100 \%$ WCGF-A. Steers dosed with WCGF-A recovered more quickly from the acidosis challenge than steers dosed with corn (Figure 2). Although WCGF-A did not eliminate ruminal acidosis, it did reduce the length of time cattle were exposed to the insult. The reduced acidosis is due to the replacement of starch, from corn grain, with a highly digestible fiber fraction, from wet CGF. In addition, the digestion of the fiber fraction of wet CGF may be partitioned throughout the digestive tract with a significant amount of NDF digestion occurring postruminally (Richards, 1996); consequently, there would be less total acid production in the rumen.

Because germ meal contains more net energy than bran, it likely has less effect on limiting acidosis than bran. Herold et al. (2000) fed dry bran and germ meal in wet CGF diets and compared ruminal metabolism results with a corn control diet. The wet CGF diets with or without germ meal induced less subacute acidosis than the dry-rolled corn diet. Ruminal $\mathrm{pH}$ measures suggested that the diet containing germ meal was fermented more rapidly than the diet without germ meal, but it did not reach the rate of acid production associated with the control corn diet.

Similar to the response observed with distillers grains, drying CGF reduces its energy value (Green et al., 1987; NCR 88, 1988; Ham et al., 1995). The cause of the reduced energy value is unknown. Milton et al. (2000) evaluated the energy value of wet bran, dry bran, or rehydrated dry bran in finishing diets. The form of bran fed had no influence on animal performance or energy value. Because drying of corn bran alone has minimal effect on the nutritional value of gluten feed, the reduced energy value of dried CGF may be due to the extensive drying of the steep or an interaction of drying bran in the presence of steep. In the laboratory, drying wet CGF at temperatures greater than $60^{\circ} \mathrm{C}$ drives off volatile compounds ( 1 to $4 \%$ of the DM; R. A. Stock, unpublished data). This loss of volatile compounds would partially explain why dry feeds have a lower energy value than wet feeds.

The metabolizable protein (MP) content of CGF diets is poorly defined. In general, the protein in CGF is highly degradable. Scott et al. (1997a) reported that WCGF-B was an excellent source of ruminally degradable amino acids and peptides. Krehbiel et al. (1995), McCoy et al. (1998), and Richards et al. (1998) observed only small numerical improvements in daily gain and feed efficiency due to the addition of escape protein to WCGF-A and WCGF-B diets. However, Klemesrud et al. (1997) observed a significant increase in daily gain of a WCGF-A finishing diet by feeding a source of ruminally protected supplemental lysine. Corn is a good source of escape protein, but it may not provide adequate amounts of lysine. Microbial protein is a good source of lysine, but it may not provide adequate amounts of lysine when cattle are fed high-concentrate diets because of reduced microbial efficiency. Herold (1999) determined that the different ingredients constituting CGF have different protein 
degradabilities; corn bran contained $13 \%$ undegraded intake protein (UIP; \% of CP), steep contained 35\% UIP, and germ meal contained $40 \%$ UIP. Thus, the MP content of CGF diets can be affected by the amount of CGF replacing corn, the amount and type (urea vs natural protein) of supplemental protein replaced by CGF, the type of CGF (amount of steep vs bran) fed, the efficiency of microbial protein production, and the amount of degradable amino acids and peptides for maximum microbial protein production.

The response of feeding added fat to wet CGF diets has been positive. The addition of 3\% tallow to wet CGF diets increased daily gain and improved feed efficiency (Herold et al., 1998; Richards et al., 1998). Lodge et al. (1997b) developed a wet CGF-based composite of ingredients to simulate wet distillers grains. The composite consisted of WCGF-A, CGM, and tallow, and it was formulated to contain $27.9 \%$ $\mathrm{CP}, 12.5 \%$ UIP, and $13.1 \%$ lipid (DM basis). The composite was fed at $40 \%$ of the dietary DM. Steers fed the composite diet were $10 \%$ more efficient $(P<.01)$ than steers fed a $40 \%$ WCGF-A diet or a dry-rolled corn control diet (Table 13). The composite contained 20\% more energy than corn.

One of the concerns with feeding by-products is an inconsistent DM content. Most wet-milling plants have limited feed ingredient inventory capabilities and, thus, the composition of the feed by-products is dictated by the wet-milling process operations. However, it is possible, although not easy, to control the DM variation of a feed by-product. The average monthly DM and CP contents and respective standard deviations for all loads of WCGF-B for 1999 were $60.13 \%, .95 \%$ and $22.40 \%, .93 \%$ (DM basis). Thus, it is possible to produce a consistent product. However, the culture within both the wet- and dry-milling industries has been to remove the feed by-products from the plant as quickly as possible to avoid interfering with the processing of grain. In addition, purchasers of feed by-products have done very little to identify the value of consistency of products in their livestock operation and to reward or discount products based on consistency of nutrient content. The feeding value of feed byproducts and the optimal utilization of the by-products can be improved if the milling industries and purchasers work together to produce, market, and use superior feed products.

\section{Implications}

Hominy feed, distillers by-products, and corn gluten feed are excellent sources of energy and protein for finishing cattle. The energy value of distillers by-products and corn gluten feed is higher when fed in the wet form than when dried. Because milling processes vary from plant to plant (type of grain fermented, type of products produced, proportion of different feed ingredients constituting the by-product), feed by-products should be evaluated on a plant-by-plant basis rather than using average book values. In addition, each cattle feeder should assess the value of the feed by-products fed in their operation to determine the optimum feeding level and the economic value in their operation.

\section{Literature Cited}

Aines, G., T. Klopfenstein, and R. Stock. 1987. Distillers Grains. MP51, Nebraska Agric. Res. Div., Lincoln.

Alexander, R. J. 1987. Corn dry milling: Processes, products, and applications. In: S. A. Watson and P. E. Ramstad (Ed.) Corn: Chemistry and Technology. pp 351-376. American Association of Cereal Chemists Inc., St. Paul, MN.

Bierman, S. J. 1995. Nutritional effects on waste management. M.S. thesis. Univ. of Nebraska, Lincoln.

Blanchard, P. H. 1992. Technology of corn wet milling and associated processes. Industrial Chemistry Library, Vol. 4. Elsevier, New York.

Fanning, K., T. Milton, T. Klopfenstein, and M. Klemesrud. 1999. Corn and sorghum distillers grains for finishing cattle. Nebraska Beef Cattle Rep. MP71-A. pp 32-33. Lincoln, NE.

Farlin, S. D. 1981. Wet distillers grains for finishing cattle. Anim. Nutr. Health. 36(No.3):35.

Firkins, J. L., L. L. Berger, and G. C. Fahey, Jr. 1985. Evaluation of wet and dry distillers grains and wet and dry corn gluten feeds for ruminants. J. Anim Sci. 60:847-860.

Fron, M., H. Madeira, C. Richards, and M. Morrison. 1996. The impact of feeding condensed distillers byproducts on rumen microbiology and metabolism. Anim. Feed Sci. Technol. 61:235245.

Green, D., R. Stock, and T. Klopfenstein. 1987. Corn gluten feed a review. Nebraska Beef Cattle Rep. MP52. pp16-18. Lincoln, NE.

Ham, G. A., R. A. Stock, T. J. Klopfenstein, and R. P. Huffman. 1995. Determining the net energy value of wet and dry corn gluten feed in beef growing and finishing diets. J. Anim. Sci. 73:353-359.

Ham, G. A., R. A. Stock, T. J. Klopfenstein, E. M. Larson, D. H. Shain, and R. P. Huffman. 1994. Wet corn distillers byproducts compared with dried corn distillers grains with solubles as a source of protein and energy for ruminants. J. Anim. Sci. 72:3246-3257.

Hanke, H. A., L. K. Lindor, J. C. Meiske, R. D. Goodrich, D. A. Larson, J. E. Garrett, and S. D. Plegge. 1982. Pressed distillers grains in diets of finishing yearling steers. Minnesota Beef Rep. B-289. pp 28-30. St. Paul, MN.

Herold, D. W. 1999. Solvent extracted germ meal for ruminants. Ph.D. dissertation. Univ. of Nebraska, Lincoln.

Herold, D., R. Cooper, T. Klopfenstein, T. Milton, and R. Stock. 1999. Corn bran, solvent-extracted germ meal, and steep liquor blends for finishing yearlings. Nebraska Beef Cattle Rep. MP71A. pp 29-31. Lincoln, NE.

Herold, D., R. Cooper, R. Mass, T. Klopfenstein, T. Milton, and R. Stock. 2000. Solvent-extracted germ meal as a component of wet corn gluten feed: Effect on ruminal acidosis. Nebraska Beef Cattle Rep. (In press).

Herold, D., M. Klemesrud, T. Klopfenstein, T. Milton, and R. Stock. 1998. Solvent-extracted germ meal, corn bran, and steep liquor blends for finishing steers. Nebraska Beef Cattle Rep. MP69-A. pp 50-53. Lincoln, NE.

Klemesrud, M., T. Klopfenstein, A. Lewis, and R. Stock. 1997. Lysine requirements for feedlot cattle. Nebraska Beef Cattle Rep. MP67-A. pp 65-67. Lincoln, NE.

Krehbiel., C. R., R. A. Stock, D. W. Herold, D. H. Shain, G. A. Ham, and J. E. Carulla. 1995. Feeding wet corn gluten feed to reduce subacute acidosis in cattle. J. Anim. Sci. 73:2931-2939.

Larson, E. M., R. A. Stock, T. J. Klopfenstein, M. H. Sindt, and R. P. Huffman. 1993a. Feeding value of wet distillers byproducts for finishing ruminants. J. Anim. Sci. 71:2228-2236. 
Larson, E. M., R. A. Stock, T. J. Klopfenstein, M. H. Sindt, and D. H. Shain. 1993b. Energy value of hominy feed for finishing ruminants. J. Anim. Sci. 71:1092-1099.

Lodge, S. L., R. A. Stock, T. J. Klopfenstein, D. H. Shain, and D. W. Herold. 1997a. Evaluation of corn and sorghum distillers byproducts. J. Anim. Sci. 75:37-43.

Lodge, S. L., R. A. Stock, T. J. Klopfenstein, D. H. Shain, and D. W. Herold. 1997b. Evaluation of wet distillers composite for finishing ruminants. J. Anim. Sci. 75:44-50.

McCoy, R. A., R. A. Stock, T. J. Klopfenstein, D. H. Shain, and M. J. Klemesrud. 1998. Effect of energy source and escape protein on receiving and finishing performance and health of calves. J. Anim. Sci. 76:1488-1498.

Milton, T., T. Klopfenstein, D. J. Jordon, R. Cooper, and R. Stock. 2000. Effect of dry, wet, or rehydrated corn bran on performance of finishing yearling steers. Nebraska Beef Cattle Rep. MP73-A. pp 61-62. Lincoln, NE.

NCR 88. 1989. Corn gluten feed in beef cattle diets. North Central Regional Res. Publ. No. 319. Ohio Agric. Res. and Dev. Center, Wooster, $\mathrm{OH}$.

Richards, C. J. 1996. Evaluation of grains and grain byproducts for ruminants. M.S. thesis. Univ. of Nebraska, Lincoln.

Richards, C., R. Stock, and T. Klopfenstein. 1996. Evaluation of levels of wet corn gluten feed and addition of tallow. Nebraska Beef Cattle Rep. MP66-A. pp 61-63. Lincoln, NE.
Richards, C. J., R. A. Stock, T. J. Klopfenstein, and D. H. Shain. 1998. Effect of wet corn gluten feed, supplemental protein, and tallow on steer finishing performance. J. Anim. Sci. 76:421-428.

Risk, J. E., K. S. Hendrix, T. W. Perry, and R. P. Lemenager. 1982. Distillers and brewers grains feeding. Indiana Beef Cattle Day Rep., Purdue Univ., West Lafayette, IN.

Rouse, G. and A. Trenkle. 1980. Stillage from grain alcohol as a feed source for cattle. A.S. Leaflet R307:1-2. Iowa State Univ., Ames.

Scott, T., T. Klopfenstein, D. Shain, and M. Klemesrud. 1997a. Wet corn gluten feed as a source of rumen degradable protein for finishing steers. Nebraska Beef Cattle Rep. MP67. pp A:70-72. Lincoln, NE.

Scott, T., T. Klopfenstein, R. Stock, and M. Klemesrud. 1997b. Evaluation of corn bran and corn steep liquor for finishing steers. Nebraska Beef Cattle Rep. MP67-A. pp 72-74. Lincoln, NE.

Watson, S. A. 1988. Corn marketing, processing, and utilization. In: G. F. Sprague and J. W. Dudley (Ed.) Corn and Corn Improvement (3rd Ed.). pp 881-940. American Society of Agronomy Inc., Madison, WI.

\section{Notes}

1. Correspondence : P. O. Box 530, 1762 Washington, Suite 101, Blair, NE 68008-0530 (phone : 800-3178825 ; fax : 402-533-4137 ; E-mail : rick_stock@cargill.com). 
Table 1. Effect of level of hominy feed on heifer performance ${ }^{a}$

\begin{tabular}{lccccc}
\hline Item & 0 & 13.3 & 26.7 & 40.0 & SEM \\
\hline Daily DMI, kg & & 10.92 & 10.91 & 10.69 & .16 \\
Daily gain, kg & 10.50 & 1.69 & 1.68 & 1.66 & .04 \\
Gain/feed & 1.66 & .155 & .155 & .155 & .003 \\
\hline
\end{tabular}

${ }^{\mathrm{a} D a t a}$ pooled across main effects of hominy feed and fat as reported by Larson et al. (1993b).

${ }^{\mathrm{b}}$ Hominy feed level, quadratic $(P=.01)$.

Table 2. Effect of hominy feed on steer performance ${ }^{a}$

\begin{tabular}{lccc}
\hline Item & 0 & 40.0 & SEM \\
\hline Daily DMI, kg & & 11.00 & .35 \\
Daily gain, kg $^{\text {Gain/feed }}$ & 10.20 & 1.63 & .04 \\
Ga $^{\mathrm{c}}$ & 1.59 & .150 & .005 \\
\hline
\end{tabular}

${ }^{\text {a } D a t a ~ p o o l e d ~ a c r o s s ~ m a i n ~ e f f e c t s ~ o f ~ h o m i n y ~ f e e d ~ a n d ~ f o r a g e ~ l e v e l ~ a s ~}$ reported by Larson et al. (1993b).

${ }^{\mathrm{b}}$ Hominy feed effect $(P=.05)$.

${ }^{\mathrm{c}}$ Hominy feed effect $(P=.18)$.

Table 3. Energy value of distillers grains for beef cattle

\begin{tabular}{lcc}
\hline Reference & $\begin{array}{c}\text { Amount in diet, } \\
\text { \% of DM }\end{array}$ & $\begin{array}{c}\text { Energy value, } \\
\% \text { of corn }\end{array}$ \\
\hline Rouse and Trenkle (1980) & 15 & 116 \\
Farlin (1981) & 21.25 & 100 \\
& 42.50 & 124 \\
Hanke et al. (1982) & 63.75 & 115 \\
Risk et al. (1982) & 14.6 & 94 \\
& 10.5 & 83 \\
Firkins et al. (1985) & 24.9 & 122 \\
Average summary & 43.6 & 110 \\
& 25 & 103 \\
\end{tabular}

${ }^{\mathrm{a}}$ Reported by Aines et al. (1987). 
Table 4. Corn and wet distillers byproduct composition, percentage of DM ${ }^{\mathrm{a}}$

\begin{tabular}{lcccr}
\hline Nutrient & Corn & Wet grains & Thin stillage & WG:TS $^{\mathrm{b}}$ \\
\hline Starch & 70.3 & 9.0 & 22.0 & 13.9 \\
Crude protein & 10.1 & 25.0 & 16.8 & 21.9 \\
NDF & 10.9 & 39.4 & 11.7 & 29.1 \\
Fat & 3.8 & 13.7 & 8.1 & 11.6 \\
Ash & 1.4 & 1.4 & 5.9 & 3.1 \\
Ethanol & - & 10.7 & 12.2 & 11.3 \\
Dry matter, \% & 89.8 & 31.4 & 5.0 & 21.5 \\
\hline
\end{tabular}

${ }^{\mathrm{a}}$ Data from Larson et al. (1993a).

${ }^{\mathrm{b}}$ Wet grains to thin stillage production ratio (1.68:1), DM basis.

Table 5. Effect of level of wet distillers by-product on finishing performance of yearlings ${ }^{\mathrm{a}}$

\begin{tabular}{|c|c|c|c|c|c|}
\hline Item & 0 & 5.2 & 12.6 & 40.0 & SEM \\
\hline Daily DMI, $\mathrm{kg}^{\mathrm{b}}$ & 11.46 & 11.20 & 10.93 & 9.68 & .22 \\
\hline Ethanol intake, $\mathrm{kg} / \mathrm{d}^{\mathrm{b}}$ & 0 & .06 & .15 & .43 & .01 \\
\hline Daily gain, $\mathrm{kg}^{\mathrm{c}}$ & 1.65 & 1.71 & 1.76 & 1.76 & .03 \\
\hline Adjusted gain/feed ${ }^{\text {de }}$ & .144 & .151 & .158 & .173 & .002 \\
\hline
\end{tabular}

${ }^{\mathrm{a}}$ Data from Larson et al. (1993a).

${ }^{\mathrm{b}}$ Linear effect $(P<.01)$.

${ }^{c}$ Linear effect $(P=.07)$; quadratic effect $(P=.08)$.

${ }^{\mathrm{d}}$ Linear effect $(P<.01)$; quadratic effect $(P=.05)$.

${ }^{\mathrm{e}}$ Accounts for DM and ethanol intake.

Table 6. Effect of level of wet distillers by-product on finishing performance of calves ${ }^{\mathrm{a}}$

\begin{tabular}{|c|c|c|c|c|c|}
\hline Item & 0 & 5.2 & 12.6 & 40.0 & SEM \\
\hline Daily DMI, kg ${ }^{\mathrm{b}}$ & 8.42 & 8.74 & 8.44 & 7.91 & .13 \\
\hline Ethanol intake, $\mathrm{kg} / \mathrm{d}^{\mathrm{b}}$ & 0 & .05 & .12 & .36 & .01 \\
\hline Daily gain, $\mathrm{kg}^{\mathrm{b}}$ & 1.30 & 1.39 & 1.40 & 1.46 & .03 \\
\hline Adjusted gain/feed ${ }^{\text {bc }}$ & .155 & .158 & .164 & .177 & .003 \\
\hline
\end{tabular}

${ }^{\text {a } D a t a ~ f r o m ~ L a r s o n ~ e t ~ a l . ~(1993 a) . ~}$

${ }^{\mathrm{b}}$ Linear effect $(P<.01)$.

${ }^{\mathrm{c}}$ Accounts for DM and ethanol intake. 
Table 7. Effect of wet or dry distillers by-products on finishing cattle performance ${ }^{a}$

\begin{tabular}{lcccccc}
\hline & & & \multicolumn{4}{c}{ DDGS $^{\mathrm{b}}$} \\
\cline { 4 - 6 } Item & Control & WDB $^{\mathrm{b}}$ & Low & Medium & High & SEM \\
\hline Daily DMI, kg & 10.99 & 10.68 & 11.48 & 11.36 & 11.73 & .55 \\
${\text { Daily gain, } \mathrm{kg}^{\text {ef }}}^{1.46}$ & 1.69 & 1.66 & 1.68 & 1.71 & .12 \\
Gain/feed $^{\text {efg }}$ & .133 & .158 & .144 & .148 & .145 & .004 \\
\hline
\end{tabular}

${ }^{a}$ Data from Ham et al. (1994).

${ }^{\mathrm{b}}$ DDGS $=$ dried distillers grains plus solubles, WDB = wet distillers by-products. Concentration of ADIN (\% of $\mathrm{N}$ ) for WDB, low, medium, and high DDGS was 7.3, 5.9, 13.9, and 14.8\%, respectively.

${ }^{\mathrm{c}}$ Control vs average of DDGS composites $(P<.10)$.

${ }^{\mathrm{d}}$ WDB vs average of DDGS composites $(P<.05)$.

${ }^{\mathrm{e}}$ Control vs WDB $(P<.05)$.

${ }^{\mathrm{f}}$ Control vs average of DDGS composites $(P<.05)$.

${ }^{\mathrm{g}} \mathrm{WDB}$ vs average of DDGS composites $(P<.10)$.

Table 8. Effect of sorghum wet distillers by-products on finishing yearling performance ${ }^{a}$

\begin{tabular}{lccccc}
\hline Item & Control & WDG $^{\mathrm{b}}$ & WDGS $^{\mathrm{b}}$ & DDGS $^{\mathrm{b}}$ & SEM \\
\hline Daily DMI, kg & 12.11 & 11.97 & 12.23 & 12.49 & .38 \\
Daily gain, kg & 1.86 & 1.83 & 1.91 & 1.78 & .10 \\
Gain/feed & $.153^{\mathrm{c}}$ & $.153^{\mathrm{c}}$ & $.155^{\mathrm{c}}$ & $.142^{\mathrm{d}}$ & .003 \\
\hline
\end{tabular}

${ }^{\text {a } D a t a ~ f r o m ~ L o d g e ~ e t ~ a l . ~(1997 a) . ~}$

${ }^{\mathrm{b}} \mathrm{WDG}=$ wet distillers grains; WDGS = wet distillers grains plus solubles; DDGS = dried distillers grains plus solubles.

${ }^{\mathrm{c}, \mathrm{d}}$ Means within a row with unlike superscripts differ $(P<.05)$.

Table 9. Effect of corn or sorghum distillers grains on finishing steer performance ${ }^{a}$

\begin{tabular}{lcccc}
\hline Item & DRC $^{\mathrm{b}}$ & $\mathrm{CORN}^{\mathrm{b}}$ & SORG $^{\mathrm{b}}$ & SEM \\
\hline Daily DMI, kg & & 10.41 & 11.55 & .21 \\
Daily gain, kg $^{\mathrm{c}}$ & 10.68 & 1.80 & 1.87 & .04 \\
Gain/feed $^{\mathrm{d}}$ & 1.65 & .172 & .168 & .003 \\
\hline
\end{tabular}

${ }^{\mathrm{a}}$ Data from Fanning et al. (1999).

${ }^{\mathrm{b}} \mathrm{DRC}=$ dry-rolled corn control; $\mathrm{CORN}=$ wet corn distillers grains; $\mathrm{SORG}=$ wet sorghum distillers grains.

${ }^{\mathrm{c}} \mathrm{CORN}$ vs SORG $(P<.01)$.

${ }^{\mathrm{d}}$ DRC vs CORN and SORG $(P<.01)$. 
Table 10. Energy value of WCGF-A $A^{a}$ for beef finishing cattle

\begin{tabular}{lccr}
\hline Reference & $\begin{array}{c}\text { Amount in diet, } \\
\text { \% of DM }\end{array}$ & $\begin{array}{c}\text { Number of } \\
\text { replications }\end{array}$ & $\begin{array}{c}\text { Relative } \\
\text { feed:gain }\end{array}$ \\
\hline Bierman (1995) & 41.5 & 4 & 1.04 \\
Ham et al. (1995); Trial 1 & 35.0 & 4 & 1.06 \\
Ham et al. (1995); Trial 2 & 70.0 & 4 & 1.06 \\
& 17.5 & 4 & 1.06 \\
& 35.0 & 4 & .97 \\
Krehbiel et al. (1995) & 52.5 & 4 & 1.01 \\
Lodge et al. (1997b) & 70.0 & 4 & .97 \\
McCoy et al. (1998); Trial 1 & 87.5 & 4 & 1.01 \\
McCoy et al. (1998); Trial 2 & 35.0 & $2^{\mathrm{c}}$ & .96 \\
Average, all levels & 40.0 & $2^{\mathrm{c}}$ & 1.00 \\
Average, 20 to 60\% of diet DM & 45.0 & 12 & .98 \\
& 45.0 & 16 & .99 \\
\end{tabular}

${ }^{\mathrm{a}} \mathrm{WCGF}-\mathrm{A}=$ wet corn gluten feed, $40 \%$ DM content.

${ }^{\mathrm{b}}$ Calculated as feed:gain of control diet divided by feed:gain of treatment diet.

${ }^{\mathrm{c}}$ Individually fed cattle trial. Treatment assigned two pen replications for calculation purposes.

Table 11. Energy value of WCGF- ${ }^{a}$ for beef finishing cattle

\begin{tabular}{lccc}
\hline Reference & $\begin{array}{c}\text { Amount in diet, } \\
\text { \% of DM }\end{array}$ & $\begin{array}{c}\text { Number of } \\
\text { replications }\end{array}$ & $\begin{array}{c}\text { Relative } \\
\text { feed:gain }^{\mathrm{b}}\end{array}$ \\
\hline Richards et al. (1996) & 44.0 & 4 & .89 \\
& 42.4 & 4 & .91 \\
Scott et al. (1997a) & 86.6 & 4 & .91 \\
& 10.4 & 4 & 1.02 \\
Scott et al. (1997b) & 20.8 & 4 & .99 \\
Herold et al. (1998) & 38.2 & 4 & .97 \\
Richards et al. (1998) & 30.0 & $2^{\mathrm{c}}$ & .90 \\
Average, all levels & 60.0 & $2^{\mathrm{c}}$ & .92 \\
Average, 20 to 60\% of diet DM & 22.5 & 4 & .99 \\
\hline
\end{tabular}

${ }^{\mathrm{a}} \mathrm{WCGF}-\mathrm{B}=$ wet corn gluten feed, $60 \%$ DM content.

${ }^{\mathrm{b} C a l c u l a t e d}$ as feed:gain of control diet divided by feed:gain of treatment diet.

${ }^{\mathrm{c}}$ Individually fed cattle trial. Treatment assigned two pen replications for calculation purposes. 
Table 12. Effect of corn bran on finishing steer performance ${ }^{a}$

\begin{tabular}{lcccc}
\hline Item & DRC $^{\mathrm{b}}$ & $15 \% \mathrm{~B}^{\mathrm{b}}$ & $30 \% \mathrm{~B}^{\mathrm{b}}$ & $\mathrm{SEM}$ \\
\hline Daily DMI, kg & $10.32^{\mathrm{c}}$ & $11.57^{\mathrm{d}}$ & $11.81^{\mathrm{d}}$ & .99 \\
Daily gain, kg & $1.47^{\mathrm{c}}$ & $1.94^{\mathrm{d}}$ & $1.65^{\mathrm{c}}$ & .04 \\
Gain/feed & $.143^{\mathrm{c}}$ & $.167^{\mathrm{d}}$ & $.140^{\mathrm{c}}$ & .003 \\
\hline
\end{tabular}

${ }^{\mathrm{a}}$ Data from Scott et al. (1997b).

${ }^{\mathrm{b}} \mathrm{DRC}=$ dry-rolled corn control; $15 \% \mathrm{~B}=15 \%$ dry corn bran; $30 \% \mathrm{~B}=30 \%$ dry corn bran.

${ }^{\mathrm{c}, \mathrm{d}}$ Means within a row with unlike superscripts differ $(P<.01)$.

Table 13. Effect of wet distillers grains composite on finishing steer performance ${ }^{a}$

\begin{tabular}{lcccccc}
\hline Item & DRC $^{\mathrm{b}}$ & WCGF $^{\mathrm{b}}$ & $\mathrm{COMP}^{\mathrm{b}}$ & -FAT $^{\mathrm{b}}$ & $-\mathrm{CGM}^{\mathrm{b}}$ & $\mathrm{SEM}$ \\
\hline Daily DMI, kg & $9.75^{\mathrm{c}}$ & $9.48^{\mathrm{cd}}$ & $9.05^{\mathrm{d}}$ & $9.08^{\mathrm{d}}$ & $9.43^{\mathrm{cd}}$ & .54 \\
Daily gain, kg & 1.33 & 1.30 & 1.35 & 1.32 & 1.33 & .13 \\
Gain/feed & $.136^{\mathrm{c}}$ & $.136^{\mathrm{c}}$ & $.149^{\mathrm{d}}$ & $.146^{\mathrm{cd}}$ & $.146^{\mathrm{cd}}$ & .023 \\
\hline
\end{tabular}

${ }^{\mathrm{a} D a t a}$ from Lodge et al. (1997b).

${ }^{\mathrm{b}} \mathrm{DRC}=$ dry-rolled corn; WCGF $=$ wet corn gluten feed; COMP = distillers composite (wet corn gluten feed, corn gluten meal, and tallow); $-\mathrm{FAT}=$ composite minus tallow; $-\mathrm{CGM}=$ composite minus corn gluten meal.

${ }^{\mathrm{c}, \mathrm{d}}$ Means within a row with unlike superscripts differ $(P<.10)$. 

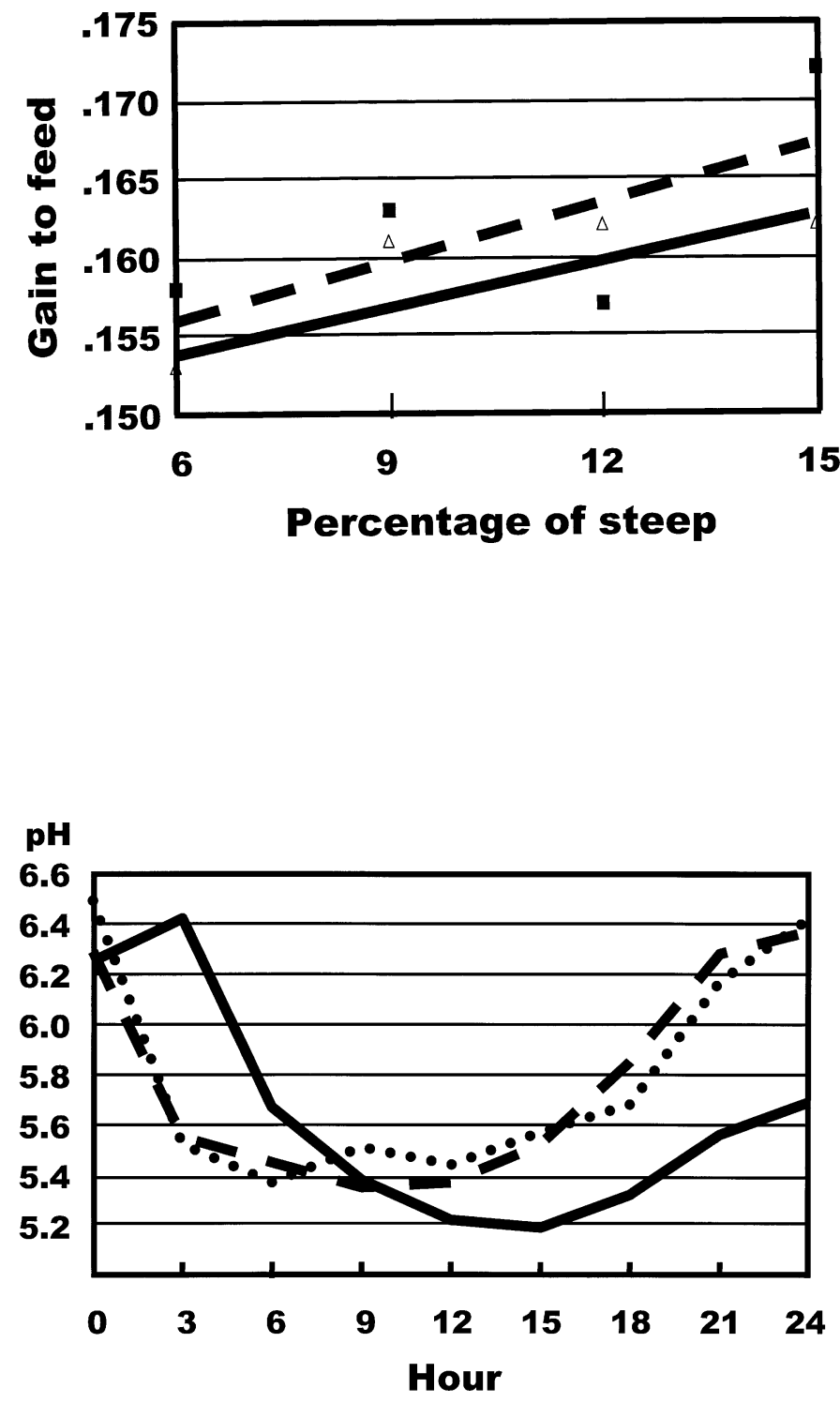

Figure 1. Bran $(-\Delta-)$ and bran/germ ( --- $\square$--- $) \times$ steep level interaction for gain/feed. Points depict actual treatment means, whereas lines are calculated estimates for feed efficiency based on linear regression. Lines are calculated as: $\mathrm{Y}=.1497 \pm .003+(.0009 \pm .0004 \mathrm{x})$ for dry corn bran and $\mathrm{Y}=.1499 \pm .006+(.0012 \pm .0009 \mathrm{x})$ for dry corn bran with solvent-extracted germ meal. Data from Herold (1999).
Figure 2. Effect of $100 \%$ dry-rolled corn ( - ), 50\% dry-rolled corn:50\% wet corn gluten feed ( ------ ), or $100 \%$ wet corn gluten feed $(. .$.$) on ruminal \mathrm{pH}$. Time $\times$ treatment interaction $(P<.01)$, SEM $=.09$. Data from Krehbiel et al. (1995). 